\title{
Zika virus in the Americas: A New Global Health Emergency
}

Nora B Molina* and Juan A Basualdo

Facultad de Ciencias Médicas, Centro Universitario de Estudios Microbiológicos y Parasitológicos, Universidad Nacional de La Plata, Argentina

*Corresponding author: Molina NB, Facultad de Ciencias Médicas, Centro Universitario de Estudios Microbiológicos y Parasitológicos, Universidad Nacional de La Plata, Argentina, Tel: 54221 423-6671; E-mail: nbmolina@med.unlp.edu.ar

Rec date: Apr 25, 2016; Acc date: Apr 28, 2016; Pub date: May 02, 2016

Copyright: (C) 2016 Molina NB, et al. This is an open-access article distributed under the terms of the Creative Commons Attribution License, which permits unrestricted use, distribution, and reproduction in any medium, provided the original author and source are credited.

\section{Editorial}

The World Health Organization (WHO) has warned of the rapid spread of Zika virus (ZIKV). In February 2016, Dr. Margaret Chan has declared the ZIKV and its suspected link to birth defects an public health emergency of international concern (PHEIC) [1-3].

ZIKV is a member of the flavivirus family, which also includes Yellow fever virus, Dengue virus, Japanese encephalitis virus, and West Nile virus. Virions are spherical (40-50 nm in diameter) with a positive-sense, nonsegmented, single-stranded RNA genome $(\sim 10.8$ $\mathrm{Kb})$. This virus has two lineages (or genotypes) different, African and Asian lineages. Information regarding pathogenesis of ZIKV is scarce but mosquito-borne flaviviruses could replicate in dendritic cells near the site of inoculation and spread to lymph nodes and the bloodstream. To date, ZIKV RNA has been detected in blood, urine, semen, saliva, cerebrospinal fluid, amniotic fluid, and breast milk [4-6]

ZIKV is transmitted to humans primarily through the bite of infected mosquitos, Aedes aegypti and Aedes albopictus [6,7]. The disease is benign and self-limiting, with a high proportion $(75-80 \%)$ of asymptomatic cases. The incubation period is short (7-12 days). People infected with ZIKV have symptoms that can include mild fever, skin rashes, conjunctivitis, muscle and joint pain, malaise or headache $[4,5]$. The illness is usually mild, with symptoms lasting from several days to a week. The diagnosis of infection ZIKV is performed in serum samples collected during the first week of infection using molecular methods such as RT-PCR to detect viral RNA. Specific IgM antibodies (ZIKV-IgM) can then be detected 4 days after onset of the infection but can give cross-react with other flaviviruses such as Dengue virus and Yellow fever virus $[6,8-10]$.

ZIKV was known as a zoonotic pathogen with sporadic human infections in Africa and Southeastern Asia. This virus was first identified in 1947 in sentinel monkey that was being used to monitor for Yellow fever virus in Uganda [4-6,8-11]. For over 50 years, few cases are reported in areas of Africa, Southeast Asia, and the Pacific Islands. The first large outbreak of disease caused by ZIKV was reported from Micronesia [11]. From 2007-2016, ZIKV was documented in 61 countries worldwide (Table 1).

\begin{tabular}{|c|c|}
\hline Period & Countries and Territorios with Zika virus \\
\hline 1947-1952 & Uganda, United Republic of Tanzania \\
\hline 1954 & Nigeria \\
\hline 1960-1983 & $\begin{array}{l}\text { Central African Republic, Senegal, Pakistan, Burkina Faso, Cote D'ivoire, Cameroon, Sierra Leone, Gabon, Indonesia, Malaysia, Costa Rica, } \\
\text { Cambodia }\end{array}$ \\
\hline 2007-2009 & Micronesia, Gabon \\
\hline 2012-2014 & French Polynesia, Isla de Pascua, Cook Islands, New Caledonia, Malaysia, Philippines, Cambodia, Indonesia, Thailand \\
\hline Jan 2015 & New Caledonia \\
\hline Feb 2015 & Brazil, Solomon Islands \\
\hline Apr 2015 & Vanuatu \\
\hline Jul 2015 & Samoa, Fidji \\
\hline Oct 2015 & Colombia, Cabo Verde \\
\hline Nov 2015 & Samoa, El Salvador, Guatemala, Mexico, Paraguay, Suriname, Venezuela \\
\hline Dec 2015 & French Guiana, Honduras, Martinique, Panama, Puerto Rico \\
\hline Jan 2016 & $\begin{array}{l}\text { Bolivia, United States, Ecuador, Virgin Islands, Dominican Republic, Costa Rica, Guadeloupe, Saint Martin, Nicaragua, Barbados, Maldives } \\
\text { Guyana, Jamaica, Curaçao, Samoa American, Samoa, Haiti, Thailand, Tonga }\end{array}$ \\
\hline Feb 2016 & Aruba, Bonaire \\
\hline
\end{tabular}




\begin{tabular}{|l|l} 
Mar 2016 & Cuba, Dominique
\end{tabular}

Table 1: Countries and territories showing historical distribution of Zika virus spread, 1947-2016 [14].

The WHO has estimated that 3-4 million cases of ZIKV in South, Central, and North America over the next 12 months. Brazil is the country most affected and health authorities have reported that potentially infected population could exceed one million cases. By 30 March 2016, many countries and territories in the Region of the Americas reported mosquito-borne transmission of the virus. Three countries have now reported locally acquired infection in the absence of any known mosquito vectors, probably through sexual transmission [11] (Table 2).

\begin{tabular}{|l|l|}
\hline Mechanism of transmission & Countries \\
\hline Mosquito-borne transmission & $\begin{array}{l}\text { Aruba, Barbados, Brazil, Bolivia, Bonaire, } \\
\text { Colombia, Costa Rica, Cuba, Curaçao, } \\
\text { Dominica, Dominican Republic, Ecuador, El } \\
\text { Salvador, French Guiana, Guadeloupe, } \\
\text { Guatemala, Guyana, Haiti, Honduras, Jamaica, } \\
\text { Martinique, Mexico, Nicaragua, Panama, } \\
\text { Paraguay, Puerto Rico, Saint Martin, Saint } \\
\text { Vincent and the Grenadines, Sint Maarten, } \\
\text { Suriname, Trinidad and Tobago, United States } \\
\text { Virgin Islands, Venezuela }\end{array}$ \\
\hline $\begin{array}{l}\text { Person-to-person } \\
\text { transmission }\end{array}$ & Argentina, Chile, USA \\
\hline
\end{tabular}

Table 2: Classification of ZIKV transmission in the Americas (2016) [11].

Human ZIKV infection appears to have changed in character while expanding its geographical range. The change is from an endemic infection causing mild illness to an infection causing large outbreaks, probably linked with neurological disorders including congenital microcephaly (CM) and Guillain-Barré syndrome (GBS).

There is a possible association between ZIKV and CM in newborn with maternal ZIKV infection. Infants with CM can have neurological sequelae, seizure, intellectual disability, vision or hearing problems, and developmental problems. $[3,11]$. In the last six months, an increase of this neurological condition has been reported in Brazil (944 cases). Other countries that have reported cases were Cabo Verde ( 2 cases), Colombia (32), French Polynesia (8), Martinique (1) and Panama (1) [11].

The incidence of neurological symptoms associated with ZIKV infection is a distinctive feature. Some adults with ZIKV and neurologic conditions like GBS were also described [5,12]. Thirteen countries have reported an increased incidence of GBS potentially related to ZIKV infection: Brazil, Colombia, Dominican Republic, El Salvador, French Guiana, French Polinesia, Haiti, Honduras, Martinique, Panama, Puerto Rico, Suriname, and Venezuela [11].

Vector-borne diseases account for $22 \%$ of the estimated global burden of communicable diseases. No effective vaccine or medication is available for some diseases, and vector control is the only option. Prevention of ZIKV infection is to avoid mosquito bites. The use of air conditioning systems, mosquito nets, appropriate clothing that covers the entire body, and applying insect repellents are the main preventive measures. In particular, WHO recommends that pregnant women avoid travel to endemic areas with ZIKV. The sexual partners of pregnant women, living in or returning from areas with the virus, should use safer sexual practices or abstinence from sexual activity for the pregnancy $[4,6,11,13,14]$.

At present, information regarding ZIKV is scarce. To prevent and control ZIKV infection in humans, we must understand the viral pathogenesis, the lineages circulating, the modes of transmission (mosquito-borne transmission and person-to-person transmission), the risks associated with infection, the impact of climate change in the vectors, the etiology of neurological disorders, and the natural history of ZIKV disease.

\section{References}

1. Media centre. World Health Organization. Accessed on 02 April 2016.

2. Heymann DL, Hodgson A, Sall AA, Freedman DO, Staples JE, et al. (2016) Zika virus and microcephaly: why is this situation a PHEIC? The Lancet 387: 719-721.

3. Chen HL, Tang RB (2016) Why Zika virus infection has become a public health concern? J Chinese Med Assoc in press.

4. Zika virus: symptoms, diagnosis, and treatment. Centers for Disease Control and Prevention. Accessed on 05 April 2016.

5. Kruger RP (2016) Zika Virus on the Move. Cell 164: 585-586.

6. Zika Virus and complications. World Health Organization. Accessed on 18 April 2016.

7. Grard G, Caron M, Mombo IM, Nkoghe D, Mboui Ondo S, et al. (2014) Zika Virus in Gabon (Central Africa)-2007: A New Threat from Aedes albopictus? PLoS Negl Trop Dis 8: e2681.

8. Rodriguez-Morales A (2015) Zika: the new arbovirus threat for Latin America. J Infect Dev Ctries 9: 684-685.

9. Fauci AS, Morens, DM (2016) Zika Virus in the Americas-yet another arbovirus threat. N Engl J Med 374: 601-604.

10. Hayes EB (2009) Zika virus outside Africa. Emerg Infect Dis 15: 1347-1350.

11. ZIKA virus Microcephaly and Guillain-Barré Syndrome. World Health Organization. Accessed on 01 April 2016.

12. Oehler E, Watrin L, Larre P, Leparc-Goffart I, Lastère S, et al. (2014) Zika virus infection complicated by Guillain-Barré syndrome-case report, French Polynesia, December 2013. Euro Surveill 19: pii 20720.

13. Wilson ME (2016) Aedes and the triple threat of DENV, CHIKV, ZIKV e Arboviral risks and prevention at the 2016 Rio Olympic Games. Travel Med Infect Dis 14: 1-4.

14. Countries and territories showing historical time-line of Zika virus spread (1947-2016). World Health Organization. Accessed on 13 April 2016. 